\title{
The analysis of the ancient Chinese commodity economy and the western economics theory
}

\section{Mini Review}

The western economic theory, which is the current mainstream of economics in China, was transplanted with the spread of modern western science after the Opium War. Because of the different historical background, western economic theory has many problems and paradoxes when explaining the Chinese problem, including its principles and concepts. The above problems are particularly obvious when the western economic theory explains the problems of the small peasant economy and commodity economy in ancient China $^{1}$. The analysis of the problems and current situation of Chinese history cannot be carried out separately because of its special national and historical background. Therefore, the analysis of the long-term characteristics of China's economic operation with the western economic theory cannot be complete and accurate.

The "western economics" is not a fixed and precise concept, it contains the summarized observation, thinking and theory as follows: from the beginning of the 14-15 century, the feature of the "capitalist" economic activities in some Western European countries in the process of gradual evolution. Based on these characteristics, economists summed up the basic principles of economic behavior analysis, such as the starting point of observation and analysis, always focused on commodity and commodity production, exchange, market, social division of labor, the formation of value and price and so on. For more than a hundred years in China, this kind of problem has also become the most popular concern in the Chinese economic circle. This was more common after the 1980 s.

It is very obvious that many famous economists insist that the analysis of social economy with the commodity market concept is generally applicable to any society, any nation, any era and any environment, therefore ancient China is no exception ${ }^{2}$. In the general impression of people, it is closely related to social division of labor, optimum distribution of resources and the development of productivity. Thus in any social form, the commodity economy is a core element and key symbol of social and economic development. The degree of development of commodity economy is not only the scale of the overall level of economic development, but also the scale of thousands of years' China ancient social development. For these

${ }^{1}$ Lin Gang (2006) The Smithian dynamics and its influence on China's economy, in the study of China's economic history. Fourth phase.

${ }^{2}$ This view is also common even in some high level academic monographs. For example, Zhu Jiaming in the preface of his monograph,"From free to monopoly: two thousand years' monetary economic in China" (Taipei, Juliu press, 2012), has given the following ideas, "Trading relationship of China traditional monetary economy..... It is based on private ownership of property rights and market economy. In other words, the interdependence of monetary economy, private property rights and commodity markets supports the development of China's traditional monetary economy, and determines the mode of existence, the mode of ownership and the mode of distribution of wealth". In the so-called famous scholars, especially in the contemporary economic theory scholars, similar concepts are indeed many; the view of "California school" is typical. Because the length of the article is limited, the author doesn't discuss much here.

\author{
Volume 2 Issue I - 2018 \\ Lin Gang,Wang Daren \\ Institute of economics Chinese academy of social sciences, \\ China
}

Correspondence: Lin Gang, Institute of economics Chinese academy of social sciences, China, Email g18936@163.com

Received: November 16, 2017 | Published: January 04, 2018

economists, "commodity" or "market" is a concept that does not need to be defined in economic analysis.

However, at least in the case of China, this kind of understanding of commodity market economy and the analysis of history and current issues based on this understanding, whether it can withstand the test of history, need to be seriously studied. It is well known that in recent years, a series of important disputes in historians and economists, such as, "centering-around-China modes", "the great divergence theory", the historical development level is closely related with the use of GDP compared to the problem, and so on, are inseparable and how to understand the type and evolution of commodity market economy.

According to common sense, this kind of mistake shouldn't have appeared. Human living environment is diverse; people in different environments will be different production methods and lifestyle to adapt. Just like the Nomadic people who live in the deserts of Africa, as long as they are still living in the original environment, their mode of production cannot be transformed into Western Europe "capitalism". But it is ridiculous that some people use the commodity economy theory which was born in eighteenth Century to analyze Western European capitalism to analyze China's economic problems. It is not only used to analyze the commodity economy of contemporary China, but also has been applied to modern and ancient times.

For a long time, some scholars have made very important expositions on the nature and characteristics of the commodity market in Chinese history. Wu, Chengming, in the middle of the 1980s, had a thought-provoking mind about the essence and characteristics of commodity production in China. Mr. Wu believes that the formation of various markets in history does not necessarily depend on the division of labor". He also insisted that there could be different exchanges in history, until we could say commodities with different meanings ${ }^{3}$. Fang, Xing divides the commodity production in small peasant economy into four types, three of which are combined with agriculture and self-sufficient economy ${ }^{4}$. Huang, Philip pointed out that there were three different types of commercialization in Chinese History: commercialization promoted by class exploitation;

${ }^{3}$ Wu Chengming (1996) Market Modernization, discussion on Economic History. The Yunnan University press pp. 217.

${ }^{4}$ Fang Xing (2004) Natural economy and commodity economy in feudal society, in manuscripts of chinese feudal economy discussion. The commercial press pp. 214-216. 
commercialization promote by subsistence or by paying for the direct expenditure of production and maintenance of life or, and to promote commercialization by profit ${ }^{5}$ ". Pei Xiaolin's series of papers put forward the concept of "limit of land productivity" after the rigorous demonstration. He also establishes a dynamic model, which consists of three layers in space: material, economy and institution, and consists of three layers in time: land use in the three development stages before population trap, population trap and after population trap ${ }^{6} . T$ he theoretical basis of "western economic theory" is questioned, it is not only difficult to explain the economic development outside the western world, but also even to the West itself.

Starting from the analysis of the characteristics of Chinese civilization, this dissertation attempts to use the acknowledged historical materials to explain my views on the commodity economy in ancient China. This paper consists of five aspects: First, the social and economic characteristics of ancient China, including the adverse effects of natural environment and geographical factors on the exchange of China's economic operation, and the favorable conditions for the development of primitive agriculture and the problems of early families' emergence. Second, the main social and economic problems of ancient China, including the proportion of human resources and land, the imbalance of population and resources, and the main characteristics of small peasant economy and survival criteria and so

${ }^{5}$ Huang Philip (1992) The peasant family and rural development in the Yangzi delta, 1350-1988. Zhonghua book company pp. 91-106.

${ }^{6} \mathrm{Pei}$ Xiaolin (2008) On the limit to land productivity: Towards an improved Malthusian Theory with regard to equal distribution of land in China. In: The Rural studies in China, Sixth Series. pp. 221-266.

Pei Xiaolin (2013) The Law of the Limit to Land Productivity and China's Hidden Agricultural Revolution. in The Rural studies in China, Tenth series pp. $90-141$. on. Third, the value orientation of governing the people's livelihood, focuses on the analysis of the pre Qin period of ancient thinkers and politicians' governing idea which pays special attention to agricultural farmers. Fourth, the influence of peasant household production combined with commodity production on the social and economic development of the whole country, including different types of poor commodity exchange, poverty type exchange, and the mechanism of western market economy. Fifth, the eastern and western cultural differences lead to different connotations of commodity economy theory. The author proposes: from the surface, how to use the GDP framework to analyze the economic situation is a methodological problem. But in fact, it is a problem of historical view how to evaluate history, how to understand the characteristics and basic laws of the long run of history, and whether it can make a comparative study of cross country, cross society and cross times with a universal value standard.

This dissertation concludes that in external form and inner nature, China ancient commodity market concept and western modern economics are significantly different. It is only when we recognize China's national economics has its own way of development, can we understand the characteristics of China deeply and construct a theoretical basis for understanding the "China issue". Therefore, it is necessary to establish the evaluation standard of social development in line with China's special national conditions.

\section{Acknowledgment}

None.

\section{Conflict of Interest}

None. 